\title{
Regulation of Homer and group I metabotropic glutamate receptors by nicotine
}

\author{
J. K. Kane,${ }^{1}$ Y. Hwang, ${ }^{1}$ O. Konu ${ }^{2}$ S. E. Loughlin, ${ }^{3}$ F. M. Leslie ${ }^{3}$ and M. D. Li ${ }^{1}$ \\ ${ }_{1}^{1}$ Department of Psychiatry, The University of Texas Health Science Center at San Antonio, San Antonio, TX 78229, USA \\ ${ }^{2}$ Department of Molecular Biology and Genetics, Bilkent University, Ankara, 06800 Turkey \\ ${ }^{3}$ Department of Pharmacology, The University of California, Irvine, CA 92697, USA \\ Keywords: expression, Homer, mGluRs, plasticity, real-time RT-PCR
}

\begin{abstract}
The present study focuses on the nicotine-induced modulation of mRNA and protein expression of a number of genes involved in glutamatergic synaptic transmission in rat brain over different time periods of exposure. A subchronic ( 3 days) but not the chronic (7 or 14 days) administration of nicotine resulted in the up-regulation of Homer2a/b mRNA in the amygdala while in the ventral tegmental area (VTA) no change in expression of either Homer2a/b or Homer1b/c was observed. Although the increase in Homer2a/b mRNA was not translated into the protein level in the amygdala, a slight but significant up-regulation of Homer1b/c protein was observed in the same region at day 3 . Both Homer forms were up-regulated at the protein level in the VTA at day 3. In the nucleus accumbens, 14 days of nicotine treatment up-regulated mRNA of Homer2b/c by $68.2 \%(P<0.05)$, while the short form Homer1a gene was down-regulated by $65.0 \%$ at day $3(P<0.05)$. In regard to other components of the glutamatergic signalling, we identified an acute and intermittent increase in the mRNA and protein levels of mGluR1 and mGluR5 in the amygdala. In the VTA, however, the effects of nicotine on mGluR mRNA expression were long-lasting but rather specific to mGluR1. Nevertheless, mGluR1 protein levels in the VTA area were up-regulated only at day 3 , as in the amygdala. These data provide further evidence for the involvement of nicotine in the glutamatergic neuronal synaptic activity in vivo, suggesting a role for the newly identified Homer proteins in this paradigm.
\end{abstract}

\section{Introduction}

Previous microarray experiments completed in this laboratory to study the effects of nicotine in different rat brain regions provided a set of candidate genes that may be responsible for the changed cellular environment in the presence of nicotine (Konu et al., 2001; Li et al., 2002). Among them, a candidate gene named Homer2b/VESL2 was found to be up-regulated by nicotine in the amygdala and ventral tegmental area (VTA) of the rat brain. Homer proteins can bind to and regulate the cellular distribution of the metabotropic glutamate receptors (mGluRs) (Brakeman et al., 1997; Kato et al., 1997; Kato et al., 1998). Homer proteins also function as scaffolding proteins connecting the metabotropic glutamate group I receptors (i.e. mGluR1 and mGluR5) to the intracellular phosphatidylinositol signalling pathway (Tu et al., 1998; Soloviev et al., 2000a).

The Homer family is made up of three genes named Homer1, 2 and 3 that have several alternatively spliced transcripts (Xiao et al., 2000). The long isoforms of Homer (Homer1b/c and Homer2a/b), but not the short isoform Homer1a, are constitutively expressed (Soloviev et al., $2000 \mathrm{~b}$ ) and contain a carboxyl terminal coiled-coil domain used in forming multimeric Homer complexes. The Homer long isoforms are enriched at postsynaptic sites and coimmunoprecipitate with the group I mGluRs (Xiao et al., 1998). Homer also associates with the ShankPSD-95-NMDA complex, providing a role for mGluR and Homer to

Correspondence: Dr Ming D. Li, as above.

E-mail: lim2@uthscsa.edu

Received 16 September 2004, revised 14 November 2004, accepted 15 December 2004 modulate $N$-methyl-D-aspartate receptors (NMDARs) (Naisbitt et al., 1999; Tu et al., 1999). Homer1b prevents mGluR5 expression on the cell surface by keeping it on the endoplasmic reticulum of the secretory pathway (Roche et al., 1999). Homerla, on the other hand, does not impede the expression of mGluR5 and has been shown to increase cell surface expression of mGluR $1 \alpha$ (Ciruela et al., 1999) while preventing clustering of group I mGluRs (Tu et al., 1998). Further study into Homer1 proteins reveals a complex interplay of Homer1 isoforms and the cell surface targeting of mGluR5 upon neuronal excitation (Ango et al., 2000). Homer is thus becoming an important player in the postsynaptic response to glutamatergic activation.

mGluRs are coupled to $G$ protein second messenger pathways and modulate glutamate neurotransmission in the brain. Both the fast excitatory transmission ionotropic glutamate receptors (iGluRs) and the mGluRs are involved in neuroplasticity (Ottersen \& Landsend, 1997; Anwyl, 1999). NMDA and alpha-amino-3-hydroxy-5-methyl-4isopropinonate (AMPA) ionotropic glutamate receptors are known to participate in long-term potentiation (LTP) and long-term depression (LTD) of neurons (Asztely \& Gustafsson, 1996; Xie et al., 1992). The number, location and gating characteristics of these ionic receptors are important in determining synaptic strength. It has been suggested that drugs of abuse, such as nicotine, that produce long-term neuronal changes by altering the steady state of intracellular signalling molecules, share mechanisms similar to those used in learning and memory (Nestler, 2002).

mGluRs and Homer proteins have been implicated in playing an important role in neural stimulation and drug addiction (Brakeman 
et al., 1997; Kato et al., 1997; Ango et al., 2000; Chiamulera et al., 2001; Swanson et al., 2001; Bottai et al., 2002; Paterson et al., 2003). It has been demonstrated that mGluR5-knockout mice lack the psychostimulant effect of cocaine injections, and a decrease in locomotor activity was observed (Chiamulera et al., 2001). These mice also had no interest in self-administering cocaine. In a separate study (Swanson et al., 2001), repeated cocaine administration blunted glutamate release into the nucleus accumbens and resulted in increased locomotor activity that accompanies intra-accumbens administration of the group I mGluR agonist (RS)-3,5-dihydroxyphenylglycine (DHPG). An investigation into this response revealed a decrease in Homer1b/c protein levels in the nucleus accumbens, suggesting that mGluR 1 and Homer1b/c are involved in the neurochemical and behavioural response to the effects of a drug of abuse like cocaine (Swanson et al., 2001). Moreover, 2-methyl-6-(phenylethynyl)-pyridine (MPEP), a specific mGluR5 antagonist, decreased nicotine self-administration by rodents, providing further support for the involvement of mGluR5 in mediating the reinforcing effects of the drugs of abuse (Paterson et al., 2003). Finally, Homer-knockout mice displayed behavioural and biochemical characteristics similar to those observed after withdrawal from repeated cocaine administration, pointing to the role of Homers in sensitivity to drugs of abuse (Szumlinski et al., 2004).

The neurobiology studies of drug addiction and neuropsychiatric and many neurodegenerative diseases has focused primarily on deciphering the framework that comprises the mesocorticolimbic dopamine system. This system is generally defined by the dopaminergic neurons that originate within the ventromedial mesencephalon, such as the VTA and the substantia nigra, and terminate in limbic regions such as the striatum, amygdaloid and accumbal regions, as well as cortical areas such as the prefrontal cortex. In addition to the dopaminergic projections, there is a complex arrangement of glutamatergic, cholinergic and noradrenergic neurons that profoundly modulate dopamine's action and physiological effects (Fallon \& Moore, 1978). The primary reinforcement pathway has been characterized by the excitation of dopaminergic neurons that project from the VTA of the midbrain to the nucleus accumbens. Nicotine administration activates mesolimbic dopaminergic neurons by acting directly at postsynaptic nicotinic acetylcholine receptors (nAChRs) within the VTA. Further study has indicated that enhanced glutamatergic excitation coupled with a depressed GABAergic inhibition contribute to mesolimbic dopamine plasticity (Pidoplichko et al., 2004).

The amygdala plays a predominant role in relaying the communication network between the primary reinforcement motivation toward an abused drug and the memories that are associated with that action. The basolateral amygdala has traditionally been associated with conditioned reinforcement behaviours (Everitt et al., 1989). Lesions of the amygdala have been shown to disrupt the cue conditioning of reward-related stimuli such as drug reinforcement (Hayes \& Gardner, 2004). Stimulation of basolateral amygdala produced an increase in dopamine release in the nucleus accumbens, suggesting amygdaloid influence on the primary motor drive underlying drug reinforcement (Howland et al., 2002; Phillips et al., 2003).

In the present study, we report the region- and time-specific differences in the expression of the group I mGluR and Homer mRNA and protein levels in the nucleus accumbens, amygdala and VTA of nicotine-treated rats over a period of 3, 7 or 14 days. Based on prior evidence implicating these proteins in neuronal strength and synaptic plasticity, we hypothesize that these expressional changes are part of the cellular mechanisms responsible for the initial physiological response to nicotine administration.

\section{Materials and methods}

\section{Animals, nicotine administration and brain punches}

Male Holtzman rats (250-350 g; HSD, Madison, WI, USA) received nicotine dihydrochloride at a dose of $4.0 \mathrm{mg} / \mathrm{kg} /$ day in saline ( $\mathrm{pH}$ 7.4), or saline alone, by i.p. injection. The dose was determined in previous studies demonstrating consistent expression levels with the least amount of behaviour changes (Li et al., 2000). An initiation phase of $48 \mathrm{~h}$ was implemented to habituate the animals to the stress of the injection; this has been shown to reduce c-fos levels in response to the stress of i.p. injection (Ryabinin et al., 1999). Moreover, salinecontrol rats were handled and treated exactly as the nicotine-treated group, thereby exposing controls to the same stress-induced effects of i.p. injection. All experiments had six animals in each of the control and treatment groups except when noted. Rats were housed in wirebottomed cages at $22{ }^{\circ} \mathrm{C}$ and maintained on a 12 : 12-h light : dark cycle. Standard laboratory rat chow and water were freely available. Nicotine was administrated five times a day from 09.00 to $17.00 \mathrm{~h}$ at 2-h intervals over a period of 3, 7 or 14 days. After the indicated time of nicotine administration, rats were injected with a lethal overdose of sodium pentobarbital $(100 \mathrm{mg} / \mathrm{mL}$ i.p. $)$ and decapitated, and the brains were removed immediately for sectioning. Coronal 2-mm sections were prepared from fresh brains, using a Stoelting tissue slicer (Chicago, IL, USA). Brain punches from selected brain regions were excised using a brain punch tissue set from myNeuroLab.com (St Louis, MO, USA) based on coordinates from Paxinos \& Watson (1986). For the ventral tegmental area, each sample contained a single 1.5-mm-diameter punch that was centred in the dense field of dopamine-containing cells. For the amygdala region, each sample contained bilateral 2.0-mm-diameter dissections that were centred in the basolateral nuclear complex. Each sample for the nucleus accumbens contained the core and shell of the accumbens dissected using bilateral 2.0-mm-diameter punches. All procedures were conducted in accordance with animal use guidelines, with the approval of our Institutional Animal Care and Use Committee.

\section{RNA isolation, reverse transcription and real-time polymerase chain reaction (real-time quantitative $R T-P C R$ )}

Total RNA was isolated from corresponding regions using TRIzol reagent according to the manufacturer's protocol (Qiagen Inc., CA, USA). Three brain regions were examined in this study: the amygdala, VTA and nucleus accumbens which are all implicated to play a significant role in drug addiction. Before use, RNA samples were treated with RNAse-free DNAse I at $37{ }^{\circ} \mathrm{C}$ for $30 \mathrm{~min}$. Assessments were made with respect to the integrity of the samples through viewing of the eithidium bromide-stained $28 \mathrm{~S}$ and $18 \mathrm{~S}$ ribosomal RNA bands.

Real-time RT-PCR conditions reported here were determined by the strategy described previously (Li et al., 1997) but some modifications were made to optimize conditions (Bustin, 2000; Konu et al., 2001). Briefly, total RNA concentration of each sample was measured in duplicate using a RIBOGreen ${ }^{\mathrm{TM}}$ kit (Molecular Probes, Inc., Eugene, OR, USA). The $0.5 \mu \mathrm{g}$ of total RNA was reverse-transcribed in a final volume of $20 \mu \mathrm{L}$ containing $4 \mu \mathrm{L}$ of $5 \times$ reverse transcriptase buffer (Tris-HCl, pH 8.8, 0.1 M; KCl, $0.5 \mathrm{M}$; and Triton $\mathrm{X}-100,1 \%$ ), $\mathrm{MgCl}_{2}$, $5 \mathrm{mM}$; DTT, $10 \mathrm{~mm}$; each dNTP, $0.625 \mathrm{mM}$; RNasin, 20 units; $50 \mu \mathrm{M}$ random hexamers, $1 \mu \mathrm{L}$; and SuperScript II RNase $\mathrm{H}^{-}$reverse transcriptase, $200 \mathrm{U}$ (Gibco BRL Life Technologies, Grand Island, NY, USA). The RT mixtures were incubated at $42{ }^{\circ} \mathrm{C}$ for $1 \mathrm{~h}$ and then heated at $95{ }^{\circ} \mathrm{C}$ for $5 \mathrm{~min}$ to inactivate the reverse transcriptase. Amplification of $4 \mu \mathrm{L}$ RT mixture (equivalent to $0.1 \mu \mathrm{g}$ total RNA) 
TABLE 1. A list of genes and their primers used in real-time quantitative RT-PCR

\begin{tabular}{|c|c|c|c|c|}
\hline Gene name & Accession number & Slope of $10 \times$ dilutions & Primer sequence $\left(5^{\prime}-3^{\prime}\right)$ & Product size (bp) \\
\hline $18 \mathrm{~S}$ & X01117 & -3.3 & $\begin{array}{l}\text { AGA AAC GGC TAC CAC ATC CAA G } \\
\text { TGT TAT TTT TCG TCA CTA CCT CCC }\end{array}$ & 84 \\
\hline Homerla & & & $\begin{array}{l}\text { AAC TCA GAG CCA AGG GCT GA } \\
\text { CAT GAT TGC TGA ATT GAA TGT G }\end{array}$ & 78 \\
\hline Homer1b/c & & & $\begin{array}{l}\text { GCT ATA TTC TCC GCG CAA CCT T } \\
\text { GCA ACT CAA CGA GGC AGA CAA T }\end{array}$ & 116 \\
\hline Homer $2 \mathrm{a} / \mathrm{b}$ & NM053309 & -3.5 & $\begin{array}{l}\text { GAG TGG AAA GCG TGT GTG AG } \\
\text { CGC ATT ACA GAA GCA AAC GGA G }\end{array}$ & 65 \\
\hline mGluR1 & NM017011 & -3.4 & $\begin{array}{l}\text { ATC ATT GCC AAA CCT GAG AGG AAC } \\
\text { GCC GTT AGA ATT GGC ATT }\end{array}$ & 141 \\
\hline mGluR5 & NM017012 & -3.0 & $\begin{array}{l}\text { TTC TCT GTC CAC CAC CAA CC } \\
\text { TAT TGC TCA CGA ACT GCA CC }\end{array}$ & 51 \\
\hline
\end{tabular}

was carried out using core reagents from the $\mathrm{SYBR}^{\circledR}$ Green kit (PE Biosystems, Foster City, CA, USA), $5 \mu \mathrm{L}$ of $10 \times \mathrm{SYBR}^{\circledR}$ Green PCR buffer, $4.0 \mu \mathrm{L}$ of $25 \mathrm{mM} \mathrm{MgCl} 2,1.0 \mu \mathrm{L}$ of $12.5 \mathrm{mM}$ dNTP mix with dUTP, $1 \mu \mathrm{L}$ of sense or antisense primers $(0.1 \mu \mathrm{g} / \mu \mathrm{L})$ and $2.5 \mathrm{U}$ of AmpliTaq DNA polymerase in a total volume of $50 \mu \mathrm{L}$. The real-time RT-PCRs were initially denatured at $94{ }^{\circ} \mathrm{C}$ for $3 \mathrm{~min}$ and then were subjected to 40 cycles of denaturation $\left(94^{\circ} \mathrm{C}, 30 \mathrm{~s}\right)$, annealing $\left(60{ }^{\circ} \mathrm{C}\right.$, $30 \mathrm{~s}$ ) and extension $\left(72{ }^{\circ} \mathrm{C}, 45 \mathrm{~s}\right)$. The iCycler (Bio-Rad, Hercules, CA, USA) was used to perform the real-time quantitative RT-PCR. After the last cycle, a dissociation curve was run to check for product purity. Intensity values were based on the incorporation of fluorescent $\mathrm{SYBR}^{\circledR}$ Green dye (excitation 497, emission $520 \mathrm{~nm}$; Molecular Probes) into the double-stranded PCR products and were measured by the Bio-Rad iCycler. All genes were normalized to $18 \mathrm{~S}$ RNA expression level.

The primer sequences used for real-time RT-PCR and related information on each gene are shown in Table 1. To confirm the efficacy of the real-time PCR technique and demonstrate that each set of gene-specific primers accurately estimates a two-fold induction per PCR cycle, a 10× serial dilution of cDNA was used as template for amplification of $18 \mathrm{~S}$, Homer2a/b, mGluR1a and mGluR5 genes using gene-specific primers. The slope of the linear regression demonstrates a difference ranging from 3.0 to 3.5 cycles between each $10 \times$ dilution, which is very close to the theoretically expected value of 3.3 cycles (see Table 1). The expression level of each gene was determined using the calibration method (Winer et al., 1999). Threshold cycles $\left(C_{t}\right)$ were determined by the iCycler for both the target gene and the housekeeping gene. In this method, one of the unknown samples is termed the 'calibrator sample'; the expression of this sample is compared against all other samples analysed. The formula used is: fold induction $=2^{-[\Delta \Delta \mathrm{Ct}]}$ where $\Delta \Delta \mathrm{C}_{\mathrm{t}}=\left[\mathrm{C}_{\mathrm{t}} \mathrm{GI}\right.$ (gene of interest, unknown sample) $-\mathrm{C}_{\mathrm{t}} 18 \mathrm{~S}$ (unknown sample) $]-\left[\mathrm{C}_{\mathrm{t}}\right.$ GI (threshold cycles, calibrator sample) $-\mathrm{C}_{\mathrm{t}} 18 \mathrm{~S}$ (calibrator sample)].

\section{Western blotting analysis}

Total protein was extracted from rat brain punches obtained from an independent time-course experiment conducted specifically for protein analysis under the same paradigm as described above except that three rats in each of the control and treatment groups were used. Individual frozen brain punches were suspended in $100 \mu \mathrm{L}$ of $240 \mathrm{~mm}$ Tris- $\mathrm{HCl}$, $\mathrm{pH} 6.8$, containing $20 \% \beta$-mercaptoethanol, $8 \%$ SDS and $40 \%(\mathrm{v} / \mathrm{v})$ glycerol, and homogenized with the Sonic Dismembrator 550 sonicator (Fisher Scientific, Houston, TX, USA). Tissue debris were removed by centrifugation at $12000 \mathrm{~g}$ for $1 \mathrm{~h}$. The supernatant was electrophoresed using $8 \%$ sodium dodecyl sulphate polyacrylamide gel (SDS-PAGE) followed by blotting to nitrocellulose membranes (Immobilon-P; Sigma). Blots were then blocked with $2 \%$ nonfat dry milk for $1 \mathrm{~h}$ at room temperature and probed with antibodies against group I mGluRs (BD Sciences, San Jose, CA, USA) and Homers (kindly provided by Dr Paul Worley, The Johns Hopkins University). The respective dilution of each antibody was as follows: Homer1b/c, $1: 5000$ and Homer2a/b, $1: 5000$; mGluR1, $1: 2500$; mGluR5, 1:2500; and $\alpha$-tubulin, $1: 2500$. Immune complexes were detected with appropriate secondary antibodies and SuperSignal West Pico Chemiluminescent Substrate (Pierce Inc., Rockford, IL, USA). Blots were stripped with Restore Western Blot Stripping Buffer (Pierce Inc.). After it was determined that the membranes were free of the immunodetection reagents, they were re-probed with antibodies to $\alpha$-tubulin (for protein normalization). After the films were developed, they were scanned on a Microtek ScanMaker 8700 scanner with ScanWizard 5.5 at a resolution of 600 dpi for quantitative analysis. Scanned images were analysed with ImageQuant 5.1 (Molecular Dynamics, Sunnyvale, CA, USA). Normalized data to either 18s rRNA or tubulin were analysed using ANOVA (Systat 6.0. SPSS Inc, Chicago, IL, USA). Significant $F$-tests were followed by comparison using the Bonferroni procedure. Comparisons yielding more than $95 \%$ statistical confidence $(P<0.05)$ were considered significantly different.

\section{Results \\ Amygdala}

At day 3 of nicotine administration, an $82 \%$ increase in the expression of the longer form of Homer2a/b was observed by real-time RT-PCR analysis $(P<0.05$; Fig. 1A) within the amygdala region. Because long forms of Homers are known to cluster and aid in the intracellular signalling of group I metabotropic receptors, quantitative real-time RT-PCR was used to measure the mRNA levels of mGluR1 and mGluR5 in the amygdala region. As with Homer2a/b, mRNA expression levels of mGluR $1 \alpha(37 \%, P<0.05$; Fig. 1B) and mGluR5 $(45 \%, \quad P<0.05$; Fig. 1C) were induced on day 3 of nicotine administration but returned to control levels thereafter (see below and Fig. 4A for details).

To determine whether the protein levels also reflect an acute up-regulation by nicotine as shown with the RNA expression studies, Western blot analysis was employed under the same experimental model as used for quantitative real-time RT-PCR experiments. While 
A)

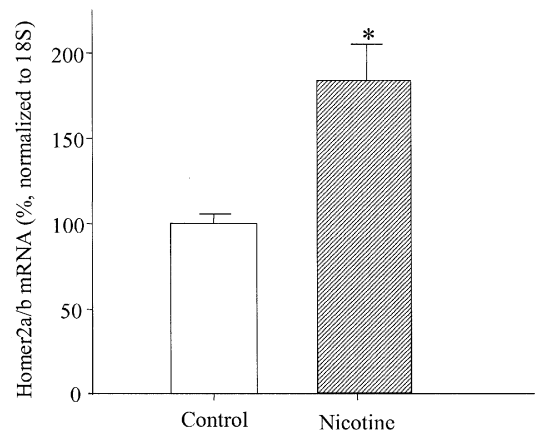

C)

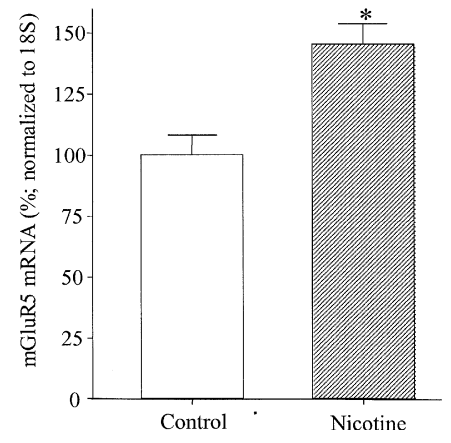

B)

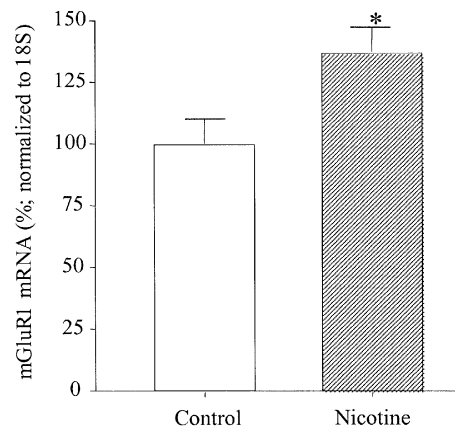

FIG. 1. Comparison of mRNA expression levels for Homer2a/b and group I mGluRs between nicotine and saline groups in the amygdala region after 3 days of nicotine administration. Using gene-specific primers, real-time quantitative RT-PCR showed (A) an $83 \%$ increase in Homer $2 \mathrm{a} / \mathrm{b}$, (B) a $37 \%$ increase in mGluR $1 \alpha$ mRNA level and (C) a $45 \%$ increase in mGluR5 mRNA level in the amygdala at day $3 .{ }^{*} P<0.05$.

(A)

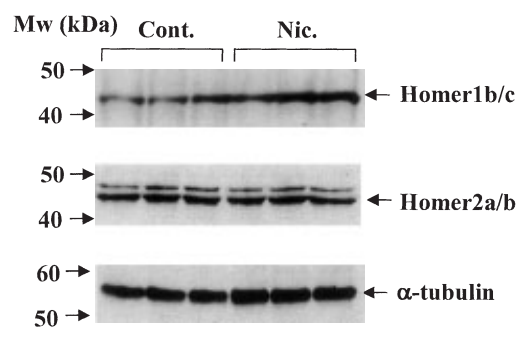

(B)

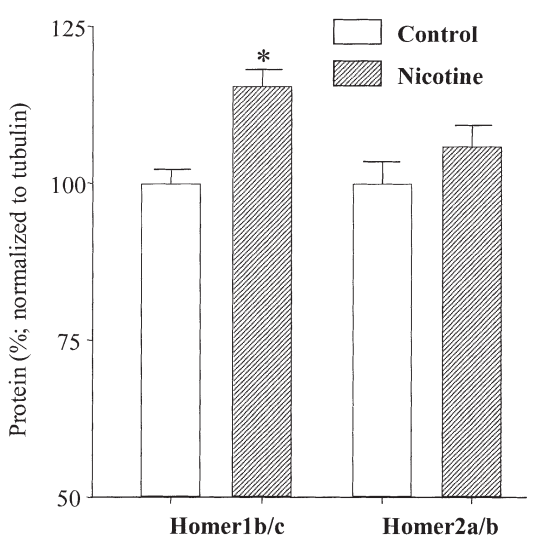

FIG. 2. (A) Western blotting analysis for Homer $1 \mathrm{~b} / \mathrm{c}$ and Homer $2 \mathrm{a} / \mathrm{b}$ at 3 days of nicotine treatment in the amygdala region. (B) Analysis indicated a $16 \%$ increase in Homer $1 \mathrm{~b} / \mathrm{c}$ protein levels while no change in Homer2a/b protein levels was observed. ${ }^{*} P<0.05$.

we did in fact observe an increase in Homer1b/c protein levels at day $3(16 \%, P<0.05)$, no significant increase in Homer2a/b protein levels was present (Fig. 2). Using commercially available monoclonal antibodies against mGluR $1 \alpha$ and mGluR5, we also measured their protein levels at 3, 7 and 14 days of nicotine administration and found that mGluR $1 \alpha$ was increased by $20 \%(P<0.05)$ by nicotine at day 3 (Fig. 3A). mGluR5 was also shown to be increased by $20 \%$ $(P<0.05)$ in the amygdala at day 3 (Fig. 3B). Homer1b/c, mGluR $1 \alpha$ and mGluR5 were all observed to return to control levels by days 7 and 14 of nicotine administration (Fig. 4B).

\section{Ventral tegmental area}

Glutamatergic neurotransmission within the VTA is important in modulating the mesolimbic dopaminergic system, thought to be critical in the primary reward response to drugs of abuse such as nicotine. We investigated the levels of the group I mGluRs and various Homer isoforms because nicotine administration is known to increase glutamatergic neurotransmission in this region. Western blot analysis showed an $18 \%$ increase in Homer1b/c $(P<0.05)$ and a $31 \%$ increase in Homer2a/b $(P<0.05$; Fig. 5$)$ proteins without a significant change at the transcript level at day 3 of nicotine treatment. Western blotting analysis also showed a significant increase in mGluR $1 \alpha$ protein at day 3 only $(15 \%, P<0.05$; Fig. 6). No significant changes were observed for mGluR5 at both the mRNA and protein levels in the VTA at any time point (Fig. 7B). On the other hand, quantitative real-time RT-PCR demonstrated a consistent increase in the expression level of mGluR $1 \alpha$ in the VTA $(60,67$ and $46 \%$ at 3,7 and 14 days, respectively, $P<0.05$; see Fig. 7A). While the mRNA expression levels of mGluR $1 \alpha$ and Homer $2 \mathrm{a} / \mathrm{b}$ seemed to be somewhat elevated over the 14 days, the protein levels of Homer1b/c, Homer2a/b and 
A)

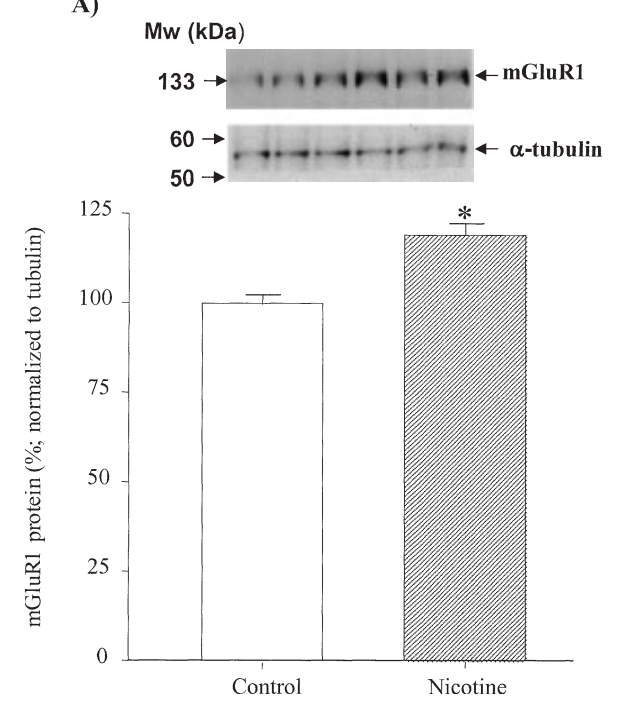

B)
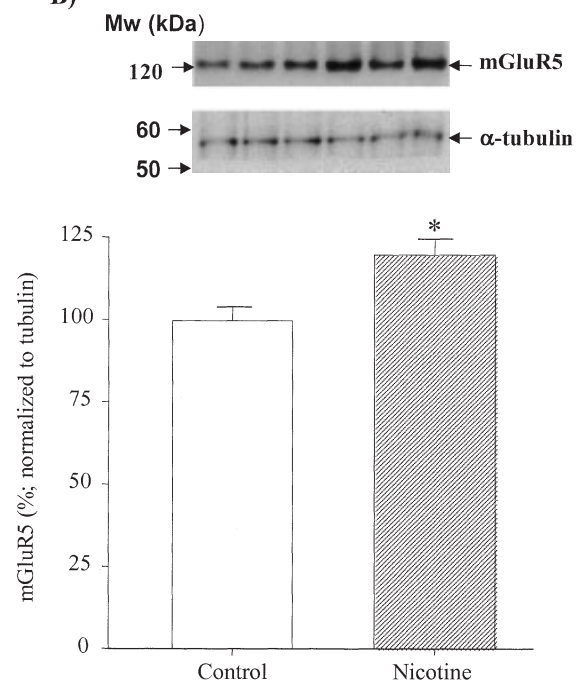

FIG. 3. Western blotting analysis for the group I mGluRs in the amygdala after 3 days of nicotine treatment. Monoclonal antibodies against the group I mGluRs revealed a complementary $20 \%$ increase in protein levels at day 3 in the amygdala for both (A) mGluR1 $\alpha$ and (B) mGluR5. $* P<0.05$.

A)

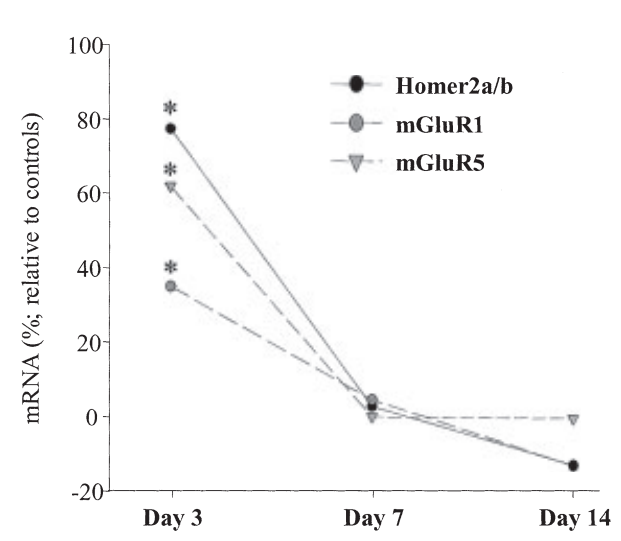

B)

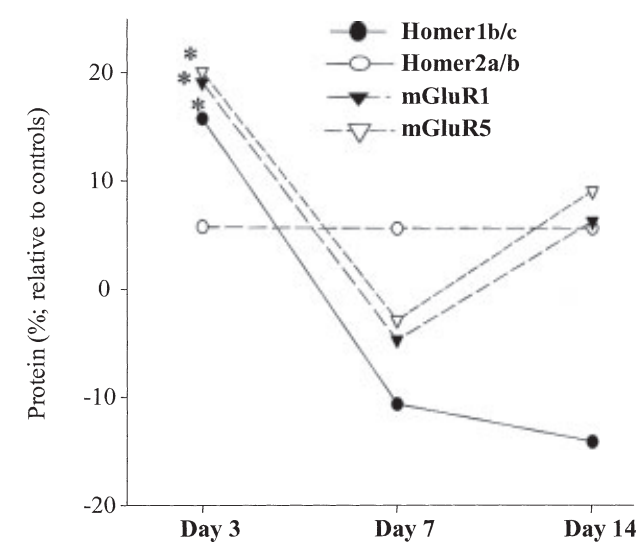

FIG. 4. Summary of expression changes in (A) mRNA and (B) protein levels for Homers and group I mGluRs over 14 days of nicotine treatment in the amygdala. There appears to be an early up-regulation of both mRNA and protein levels of group I mGluRs and Homer genes in the amygdala that return to control levels thereafter. ${ }^{*} P<0.05$.

(B)
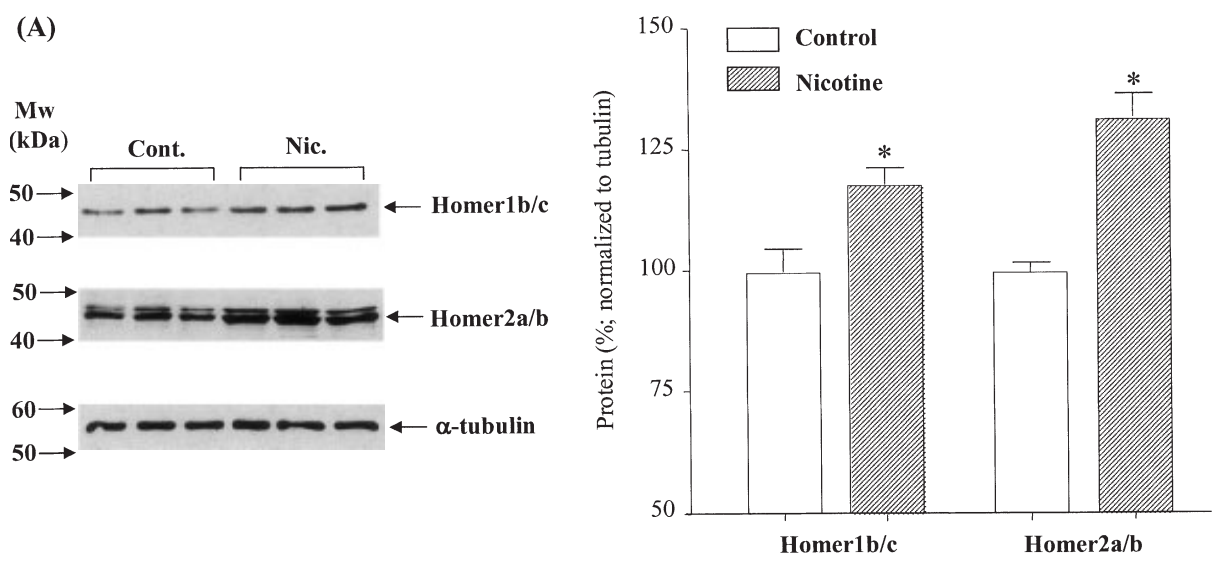

FIG. 5. Western blotting analysis for Homer $1 \mathrm{~b} / \mathrm{c}$ and Homer2a/b in the VTA region. While microarray (data not shown) and quantitative RT-PCR (see Fig. 8) show no difference in mRNA levels of Homer2a/b, Western blot demonstrated a $31 \%$ increase in protein levels. (A) A representative autoradiograph of Western analysis. (B) Consistent with an increase in Homer $2 \mathrm{a} / \mathrm{b}$ levels, Western blot analysis shows an $18 \%$ increase in Homer $1 \mathrm{~b} / \mathrm{c}$ protein levels at day 3 in the VTA. ${ }^{*} P<0.05$. 


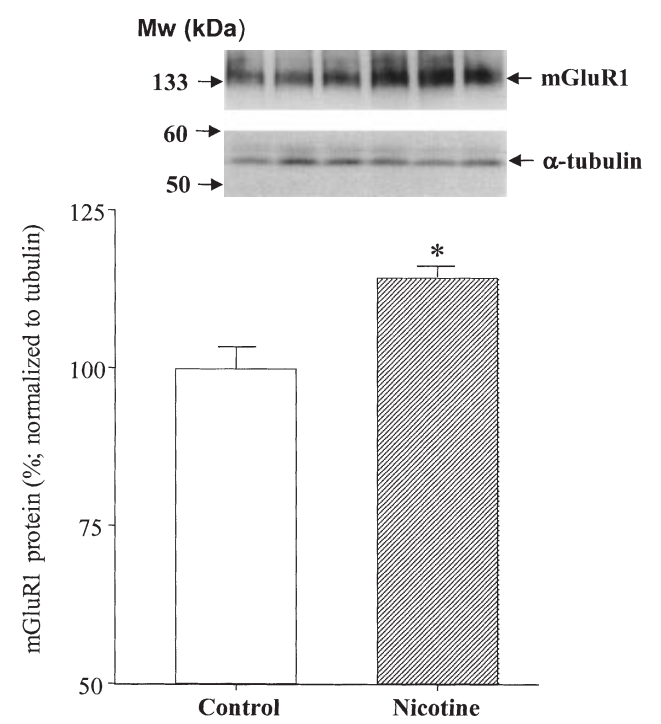

FIG. 6. Western blot analysis of the group 1 mGluR1 in the VTA. A $15 \%$ increase was observed in mGluR $1 \alpha$ protein levels. ${ }^{*} P<0.05$.

mGluR1 $\alpha$ dropped to control levels after day 3 in a fashion analogous to the amygdala region.

\section{Nucleus accumbens}

Real-time RT-PCR assays indicated that the short form Homerla and mGluR1 $\alpha$ mRNA levels in the nucleus accumbens were downregulated by $65.3 \%$ (Fig. $8 \mathrm{~A} ; P<0.05$ ) and $37.1 \%$ (Fig. 8B; $P<0.05$ ), respectively, in response to 3 days of nicotine administration. However, no significant differences were detected in these mRNA levels at 7 or 14 days of nicotine treatment (see Fig. 8D). In contrast, Homer $2 \mathrm{~b} / \mathrm{c}$ was up-regulated by $68.2 \%$ after 14 days of administration (Fig. 8C; $P<0.05$ ). Similarly, we also assayed for the expression levels of other genes mentioned in the present study at both the RNA and protein levels and found that they displayed no significant differences between the nicotine-treated and saline control groups in the nucleus accumbens (data not shown).

\section{Discussion}

Previous microarray analyses demonstrated that nicotine increased the constitutive expression of the Homer2a/b gene (Konu et al., 2001). The present study confirms the modulation of Homer $2 \mathrm{a} / \mathrm{b}$ mRNA expression in nicotine-treated rats. Interestingly, although protein levels of Homer $1 \mathrm{~b} / \mathrm{c}$ increased by $16 \%(P<0.05)$, Homer $2 \mathrm{a} / \mathrm{b}$ protein did not show significant change in the amygdala at day 3 (Fig. 2). It is possible that the protein levels for Homer $2 \mathrm{a} / \mathrm{b}$ had already begun to return to baseline at day 3, at which time the first samples were assayed. As noted at day 7 in the amygdala, the mRNA and protein levels of the genes under study were all back to control levels (Fig. 4).

Homer is a scaffolding protein involved in a complex interplay between membrane receptors and intracellular signalling. It represents an important link in the modulation of a complicated system driven by the excitatory amino acid glutamate upon target neurons. Nicotine affects glutamatergic neurotransmission by acting at nAChRs. nAChRs are located presynaptically where they modulate the release of neurotransmitters such as glutamate and postsynaptically where they affect signalling pathways (McGehee et al., 1995; Wonnacott, 1997; Aramakis \& Metherate, 1998; Guo et al., 1998). Coupled with the widespread CNS distribution of nAChRs, nicotine administration affects physiological conditions such as addiction, learning, memory and more (Levin, 1992; Levin \& Simon, 1998). The cellular adaptations upon nicotine exposure are of particular interest in attempting to explain these effects of nicotine. In this report, mRNA and protein expression analyses suggest that the different forms of Homer and mGluRs are being regulated by nicotine in these brain regions.

It has been demonstrated that nicotine regulates glutamatergic neurotransmission within the amygdala region (Girod et al., 2000; Barazangi \& Role, 2001). Our data support this with expression levels of the two group I metabotropic receptors being acutely up-regulated in the amygdala after nicotine administration. The use of monoclonal antibodies against mGluR1 and mGluR5 demonstrated that the increase in mRNA expression levels was translated into an increase in protein levels in the amygdala at day 3 . The amygdala region is known to play a central role in conditioned reinforcement (Everitt et al., 1999; Kalivas \& Nakamura, 1999; Koob, 1999; Parkinson et al., 2001) and in establishing different types of learning and memory (Maren, 1999; Walker \& Davis, 2002). Group I mGluRs are involved in the formation of synaptic plasticity (O'Connor et al., 1994; Huber
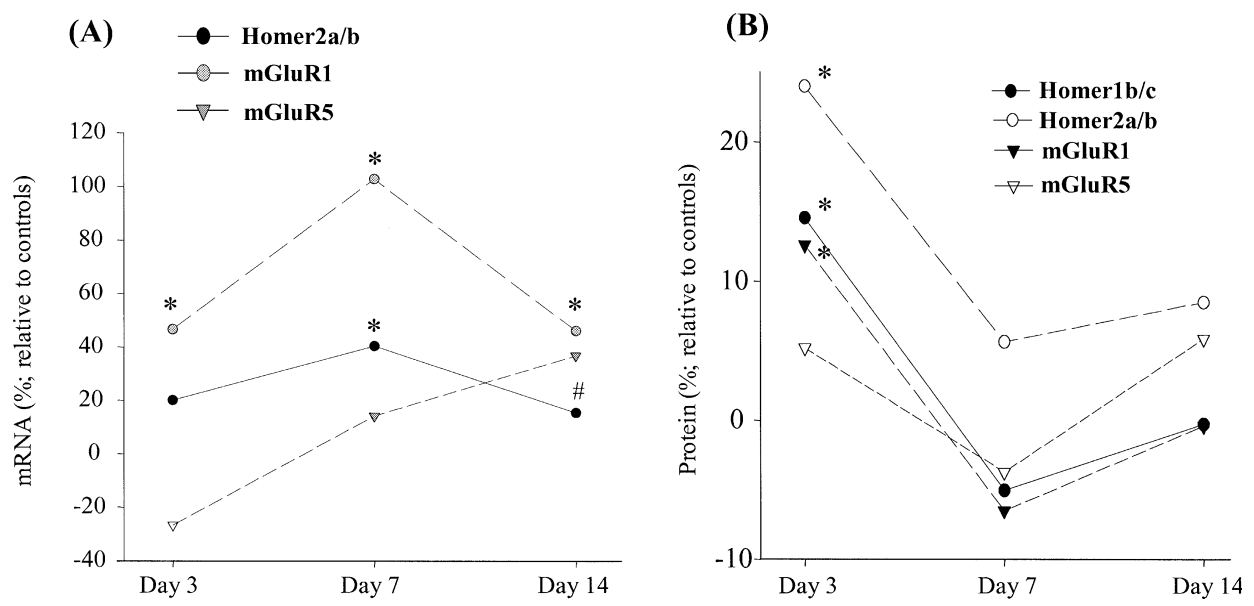

FIG. 7. Summary of the target gene (A) mRNA expression and (B) protein levels presented as the percent change relative to control in the VTA. While the protein levels of Homer $1 \mathrm{~b} / \mathrm{c}$ and mGluR1 $\alpha$ dropped in a similar fashion to that observed in the amygdala, the expression level of mGluR $1 \alpha$ remained elevated throughout the full 14 days of nicotine administration. $* P<0.05$. 

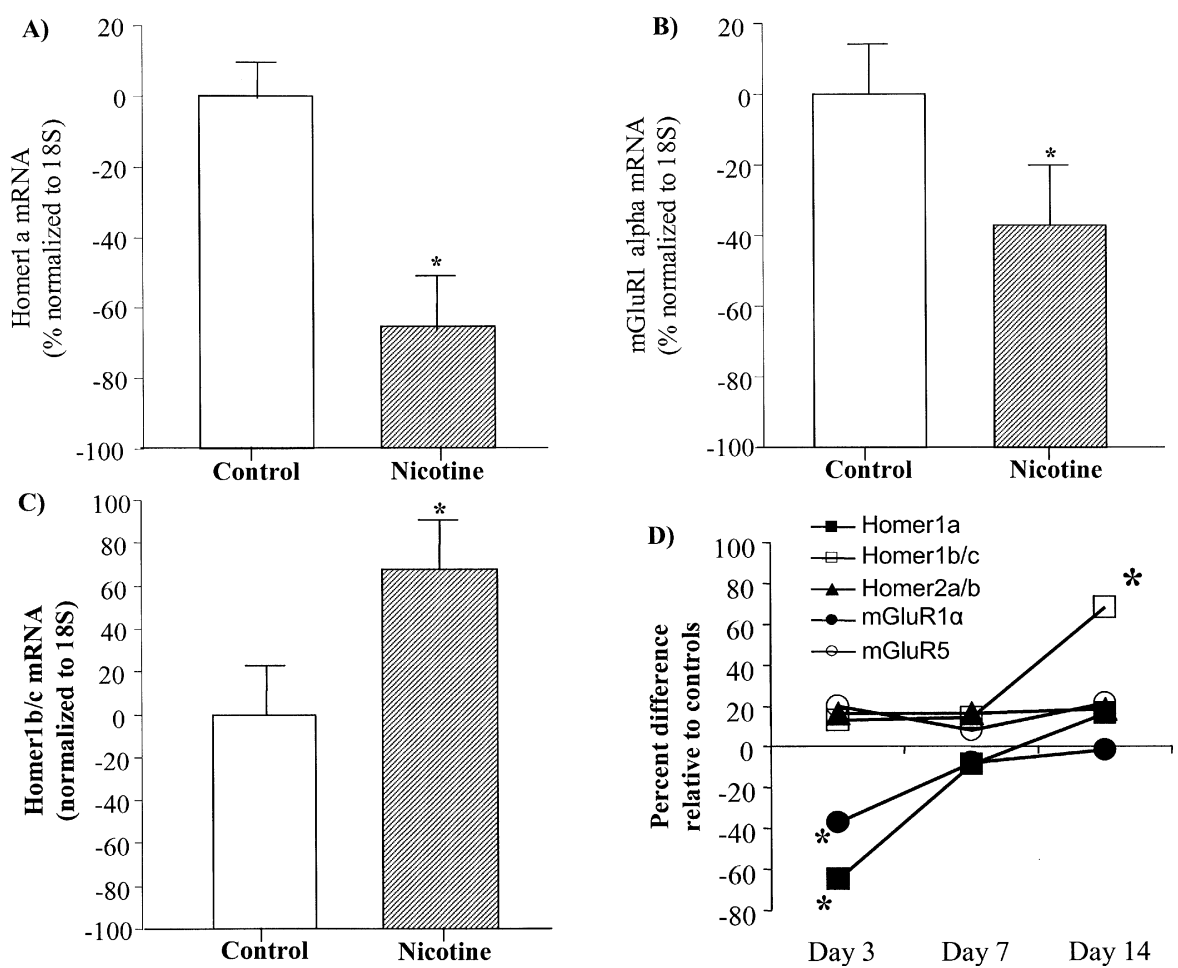

FIG. 8. A comparison of the mRNA levels of (A) Homer1a and (B) mGluR1 $\alpha$ at day 3 and (C) Homer1b/c at day 14 in the nucleus accumbens of control and nicotine-treated rats. (D) mRNA expression profiles of Homer1a, Homer1b/c, Homer2a/b, mGluR1a and mGluR5 in the nucleus accumbens at different time points of nicotine administration. ${ }^{*} P<0.05$.

et al., 1998; Balschun et al., 1999). Group I mGluRs and Homers can modulate LTP and affect the firing pattern of the target neuron (Bortolotto et al., 1999; Zheng \& Gallagher, 1992; Brakeman et al., 1997; Kato et al., 1997; Rodrigues et al., 2002). Through changing the synaptic strength of the target neuron, these processes are believed to be involved in the formation of learning and memory (Barnes, 1995; Kato et al., 1997; Turrigiano \& Nelson, 2000). The increase in glutamatergic activity in response to nicotine administration may be driving the up-regulation of group I mGluRs, as observed in the amygdala at day 3 , thereby providing a mechanism for a new level of responsiveness to the presence of glutamate. An up-regulation in the mGluR and Homer protein levels may help explain a change in the neuroplasticity within the amygdala region that is responsible for the formation of learning and memory events associated with nicotine administration.

mGluRs are also known to function postsynaptically through interaction with other glutamate receptors such as NMDARs (Naisbitt et al., 1999; Rodrigues et al., 2002). An up-regulation of both mGluR $1 \alpha$ and Homer proteins may indicate an increased association with the NMDA receptor (Fig. 9). Tu et al. (1999) demonstrated the existence of the coupling complex, mGluRs-Homer-Shank-F-actinGKAP-PSD-95-NMDAR. This complex places all receptors in close proximity to one another and also is believed to provide a bridge allowing for the efficient modulation of postsynaptic LTP via modulation of the actin cytoskeleton ( $\mathrm{Tu}$ et al., 1999). NMDA receptors play an important role in LTP formation and the group I mGluRs are known to modulate LTP through the NMDA receptors (Aniksztejn et al., 1991; Fitzjohn et al., 1996; Pisani et al., 1997; Yu et al., 1997; Rodrigues et al., 2002). Recently, Manahan-Vaughan et al. (2003) reported an increase in mGluR1 and mGluR5 protein

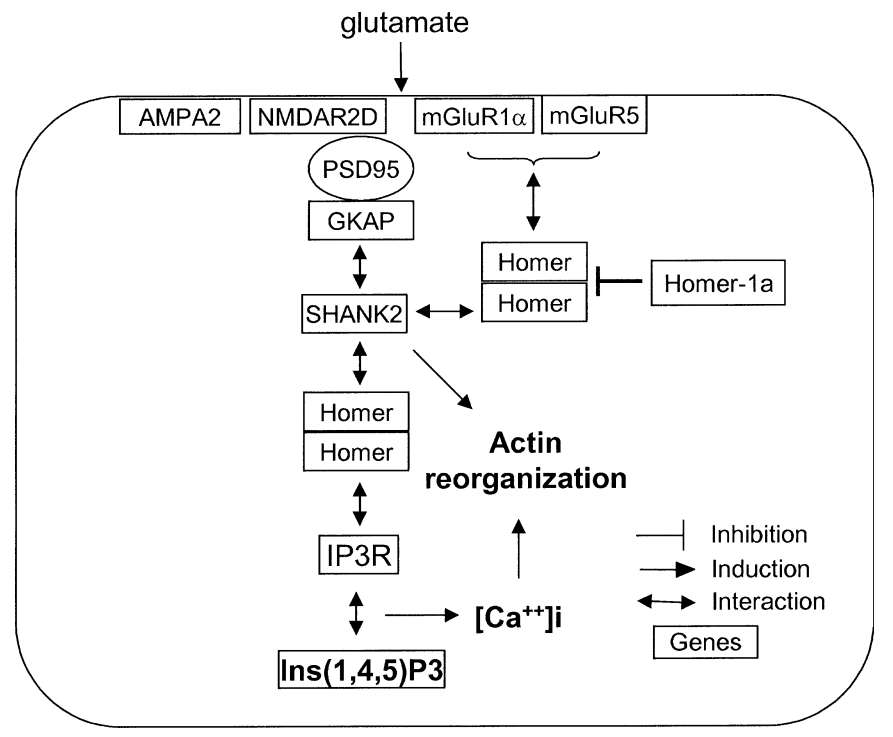

FIG. 9. Graphical representation of various interacting components of glutamatergic signalling that lead to restructuring of the actin cytoskeleton in the context of synaptic plasticity. Homer dimers allow for receptor clustering at the cell surface while increasing the intracellular $\mathrm{Ca}^{++}$levels via their interaction with IP3Rs. Homer-1a, on the other hand, may compete with Homer long forms and thus is able to modulate the strength of the synaptic complexes and cytoskeletal organization. Abbreviations of genes: AMPA2, ionotropic glutamate receptor AMPA 2; NMDAR2D, NMDA ionotropic glutamate receptor; mGluR1a, glutamate receptor metabotropic alpha 1; mGluR5, glutamate receptor metabotropic 5; PSD-95, postsynaptic density protein $95 \mathrm{kDa}$; GKAP, guanylate kinase-associated protein; SHANK2, proline-rich synapse associated protein 2; IP3R, inositol 1,4,5-trisphosphate receptor. 
levels and mGluR5 mRNA levels in the hippocampus after LTP induction, demonstrating regulation of these genes during LTP. Thus, it is reasonable to assume that the presence of nicotine increases the release of glutamate presynaptically from nerve terminals where, upon activation, postsynaptic metabotropic and ionotropic glutamate receptors modulate LTP in target neurons (see Fig. 9).

The mGluR-Homer-Shank-GKAP-PSD-95-NMDAR complex is also believed to play a role in the effective control of intracellular calcium levels through the modulation of the phosphatidylinositol signalling pathway (Nakanishi, 1994; Kawabata et al., 1998; Emptage et al., 1999; Tu et al., 1999). An increase in glutamatergic activity at this complex would indicate an increase in phosphoinositide and intracellular calcium levels (Fig. 9). In addition, Homer dimers are connected to F-actin whose reorganization is essential for spine growth and synapse formation (Sala et al., 2001). In addition to the up-regulation of mGluRs and Homer proteins, the phosphatidylinositol pathway might be modulated by nicotine via changes in the pool of available phosphatidylinositol-4,5-bisphosphate (PIP2) levels in the membrane, which can buffer actin-binding proteins. Nicotine has been shown to increase calcium levels in different types of neuronal cells (Barrantes et al., 1995; Sabban \& Gueorguiev, 2002). Recently, Conroy et al. (2003) have identified the PDZ-containing proteins that are receptor-specifically associated with neuronal nAChRs in the chick ciliary ganglion. They have suggested that PDZ-associated proteins may play a role in the maturation of nicotinic synapses as well as the transduction of the calcium signal to the downstream components. Our findings therefore directly implicate Homer proteins as intrinsic components of nAChR signalling at the postsynaptic densities.

The mesolimbic dopaminergic projection is modulated by glutamatergic action within the VTA (Kalivas et al., 1989; Taber et al., 1995). Our data revealed an increase in mGluR and Homer proteins in the VTA, suggesting a role for mGluR pathways in the glutamatergic modulation of mesolimbic dopamine neurons. The difference in responses between VTA and amygdala of Homer2a/b and mGluR5 at day 3 may be due to the different glutamatergic input and/or response mechanisms utilized by the two separate regions. However, despite the differences there is a similar up-regulation of these related gene families at the early time points of nicotine administration. Interestingly, the expression and protein levels of Homers and mGluRs generally returned to baseline at the later time points, suggesting a new level of tolerance. Behaviour observation mirrors this chronology with an increased response to nicotine administration at the earlier time points than to later administrations. Given the fundamental role the amygdala and VTA play in the physiological response of an organism to drug treatment, the increase in Homer and mGluR levels suggest a role and possible target for the type I mGluR signalling pathway in the primary reinforcement actions of nicotine.

While nicotine produces a transient activation of mesolimbic dopaminergic neurons acting at somatic nAChRs (Pidoplichko et al., 1997), Mansvelder \& McGehee (2000) demonstrated that glutamate release from glutamatergic nerve terminals was facilitated by the activation of presynaptic $\alpha 7$-containing $\mathrm{nAChRs}$, and is required for prolonged dopamine release in the nucleus accumbens. Furthermore, NMDA receptor antagonism in the VTA has been shown to decrease nicotine-elicited accumbal dopamine release (Schilstrom et al., 1998). Regardless, further pharmacological experiments will be required to determine whether the group I metabotropic glutamate signalling complex acting either at distal sites, such as the amygdala or VTA, or directly within the nucleus accumbens is involved in nucleus accumbens dopamine release in response to nicotine.

Our findings also implicated the activity-induced short form of Homer (i.e. Homer1a) as a potential modulator of the nicotine-induced synaptic activity within the nucleus accumbens region. The expression analysis demonstrated a significant decrease in Homerla and mGluR $1 \alpha$ mRNAs in the nucleus accumbens at the early time point (Fig. 8A and B), although these transcriptional changes were not immediately reflected at the level of protein expression. Interestingly, a previous study (Kato et al., 1998) indicated that LTP induced expression of Homerla mRNA but not that of the protein, possibly due to the rapid Homerla protein turnover. Homerla, which lacks a coiled-coil (CC) domain, was shown to exert negative feedback on Homer-mediated IP3 signalling possibly by competing with Homerlb/c and other long isoforms (CC-Homer), and disrupting the complex formation between CC-Homer and Shank, a component of postsynaptic density (PSD; Sala et al., 2003). Furthermore, Sala et al. (2003) have demonstrated that Homerla is important for synaptic plasticity because its presence results in the restructuring of dendritic spine morphology via changes in the dendritic dimensions and number and in the molecular composition of PSD components. Our findings suggest that the nicotine-induced synaptic activity and calcium signalling may be altered by changes in Homerla and mGluR1 expression in the nucleus accumbens. However, the cellular localization of mGluRs as well as long and activity-induced isoforms of Homer proteins should be determined upon nicotine treatment because Homer proteins are known to regulate cell-surface targeting of mGluRs upon ligand activation (Ango et al., 2002; Minami et al., 2003). Furthermore, studies that incorporate shorter intervals between experimental time points may be needed to address in detail the degree to which Homerla expression is modulated during the course of nicotine administration.

In summary, our data provide evidence for the regulation of the group I mGluRs and Homer proteins in the three brain regions (VTA, amygdala and nucleus accumbens) by systemic nicotine administration. This represents the first report demonstrating Homer regulation by nicotine. Nicotine, acting through presynaptic nAChRs on glutamatergic terminals, drives glutamate release, thereby regulating excitatory input on target neurons. Activation of the group I mGluRs, Homer proteins and the phosphatidylinositol signalling pathway may reflect a new synaptic state in the target neurons. The change in synaptic strength of these neurons may be involved in several physiological responses to nicotine administration. Future experiments are needed to investigate these connections.

\section{Acknowledgements}

We wish to thank Dr Paul F. Worley of Johns Hopkins University for providing Homers 1 and 2 antibodies. This project was supported by NIH grants DA-12844 and DA-13783 to M.D.L. and UCI TTURC, DA-13332 to F.M.L.

\section{Abbreviations}

AMPA, alpha-amino-3-hydroxy-5-methyl-4-isopropinonate; CC, coiled-coil; iGluR, ionotropic glutamate receptor; LTD, long-term depression; LTP, longterm potentiation; mGluR, metabotropic glutamate receptor; $\mathrm{nAChR}$, nicotinic acetylcholine receptor; NMDAR, $N$-methyl-D-aspartate receptor; PDZ, the postsynaptic protein PSD-95/SAP90; the Drosophila septate junction protein Discs-large, and the tight junction protein ZO-1; PSD, postsynaptic density; real-time quantitative RT-PCR, reverse transcription and real-time polymerase chain reaction; VTA, ventral tegmental area.

\section{References}

Ango, F., Pin, J.P., Tu, J.C., Xiao, B., Worley, P.F., Bockaert, J. \& Fagni, L. (2000) Dendritic and axonal targeting of type 5 metabotropic glutamate receptor is regulated by homerl proteins and neuronal excitation. J. Neurosci., 20, 8710-8716. 
Ango, F., Robbe, D., Tu, J.C., Xiao, B., Worley, P.F., Pin, J.P., Bockaert, J. \& Fagni, L. (2002) Homer-dependent cell surface expression of metabotropic glutamate receptor type 5 in neurons. Mol. Cell Neurosci., 20, 323-329.

Aniksztejn, L., Bregestovski, P. \& Ben-Ari, Y. (1991) Selective activation of quisqualate metabotropic receptor potentiates NMDA but not AMPA responses. Eur. J. Pharmacol., 205, 327-328.

Anwyl, R. (1999) Metabotropic glutamate receptors: electrophysiological properties and role in plasticity. Brain Res. Brain Res. Rev., 29, 83-120.

Aramakis, V.B. \& Metherate, R. (1998) Nicotine selectively enhances NMDA receptor-mediated synaptic transmission during postnatal development in sensory neocortex. J. Neurosci., 18, 8485-8495.

Asztely, F. \& Gustafsson, B. (1996) Ionotropic glutamate receptors. Their possible role in the expression of hippocampal synaptic plasticity. Mol. Neurobiol., 12, 1-11.

Balschun, D., Manahan-Vaughan, D., Wagner, T., Behnisch, T., Reymann, K.G. \& Wetzel, W. (1999) A specific role for group I mGluRs in hippocampal LTP and hippocampus-dependent spatial learning. Learn. Mem, 6, 138-152.

Barazangi, N. \& Role, L.W. (2001) Nicotine-induced enhancement of glutamatergic and GABAergic synaptic transmission in the mouse amygdala. J. Neurophysiol., 86, 463-474.

Barnes, C.A. (1995) Involvement of LTP in memory: are we 'searching under the street light'? Neuron, 15, 751-754.

Barrantes, G.E., Murphy, C.T., Westwick, J. \& Wonnacott, S. (1995) Nicotine increases intracellular calcium in rat hippocampal neurons via voltage-gated calcium channels. Neurosci. Lett., 196, 101-104.

Bortolotto, Z.A., Fitzjohn, S.M. \& Collingridge, G.L. (1999) Roles of metabotropic glutamate receptors in LTP and LTD in the hippocampus. Curr. Opin. Neurobiol., 9, 299-304.

Bottai, D., Guzowski, J.F., Schwarz, M.K., Kang, S.H., Xiao, B., Lanahan, A., Worley, P.F. \& Seeburg, P.H. (2002) Synaptic activity-induced conversion of intronic to exonic sequence in Homer 1 immediate early gene expression. J. Neurosci., 22, 167-175.

Brakeman, P.R., Lanahan, A.A., O’Brien, R., Roche, K., Barnes, C.A., Huganir, R.L. \& Worley, P.F. (1997) Homer: a protein that selectively binds metabotropic glutamate receptors. Nature, 386, 284-288.

Bustin, S.A. (2000) Absolute quantification of mRNA using real-time reverse transcription polymerase chain reaction assays. J. Mol. Endocrinol., 25, 169-193.

Chiamulera, C., Epping-Jordan, M.P., Zocchi, A., Marcon, C., Cottiny, C., Tacconi, S., Corsi, M., Orzi, F. \& Conquet, F. (2001) Reinforcing and locomotor stimulant effects of cocaine are absent in mGluR5 null mutant mice. Nat. Neurosci., 4, 873-874.

Ciruela, F., Soloviev, M.M. \& McIlhinney, R.A. (1999) Co-expression of metabotropic glutamate receptor type 1alpha with homer-1a/Vesl-1S increases the cell surface expression of the receptor. Biochem. J., 341 (3), 795-803.

Conroy, W.G., Liu, Z., Nai, Q., Coggan, J.S. \& Berg, D.K. (2003) PDZcontaining proteins provide a functional postsynaptic scaffold for nicotinic receptors in neurons. Neuron, 38, 759-771.

Emptage, N., Bliss, T.V. \& Fine, A. (1999) Single synaptic events evoke NMDA receptor-mediated release of calcium from internal stores in hippocampal dendritic spines. Neuron, 22, 115-124.

Everitt, B.J., Cador, M. \& Robbins, T.W. (1989) Interactions between the amygdala and ventral striatum in stimulus-reward associations: studies using a second-order schedule of sexual reinforcement. Neuroscience, $\mathbf{3 0}$, 63-75.

Everitt, B.J., Parkinson, J.A., Olmstead, M.C., Arroyo, M., Robledo, P. \& Robbins, T.W. (1999) Associative processes in addiction and reward. The role of amygdala-ventral striatal subsystems. Ann. NY Acad. Sci., 877, 412-438.

Fallon, J.H. \& Moore, R.Y. (1978) Catecholamine innervation of the basal forebrain. IV. Topography of the dopamine projection to the basal forebrain and neostriatum. J. Comp. Neurol., 180, 545-580.

Fitzjohn, S.M., Irving, A.J., Palmer, M.J., Harvey, J., Lodge, D. \& Collingridge, G.L. (1996) Activation of group I mGluRs potentiates NMDA responses in rat hippocampal slices. Neurosci. Lett., 203, 211-213.

Girod, R., Barazangi, N., McGehee, D. \& Role, L.W. (2000) Facilitation of glutamatergic neurotransmission by presynaptic nicotinic acetylcholine receptors. Neuropharmacology, 39, 2715-2725.

Guo, J.Z., Tredway, T.L. \& Chiappinelli, V.A. (1998) Glutamate and GABA release are enhanced by different subtypes of presynaptic nicotinic receptors in the lateral geniculate nucleus. J. Neurosci., 18, 1963-1969.

Hayes, R.J. \& Gardner, E.L. (2004) The basolateral complex of the amygdala mediates the modulation of intracranial self-stimulation threshold by drugassociated cues. Eur. J. Neurosci., 20, 273-280.

Howland, J.G., Taepavarapruk, P. \& Phillips, A.G. (2002) Glutamate receptordependent modulation of dopamine efflux in the nucleus accumbens by basolateral, but not central, nucleus of the amygdala in rats, J. Neurosci., 22, 1137-1145.

Huber, K.M., Sawtell, N.B. \& Bear, M.F. (1998) Effects of the metabotropic glutamate receptor antagonist $\mathrm{MCPG}$ on phosphoinositide turnover and synaptic plasticity in visual cortex. J. Neurosci., 18, 1-9.

Kalivas, P.W., Duffy, P. \& Barrow, J. (1989) Regulation of the mesocorticolimbic dopamine system by glutamic acid receptor subtypes. J. Pharmacol. Exp Ther, 251, 378-387.

Kalivas, P.W. \& Nakamura, M. (1999) Neural systems for behavioral activation and reward. Curr. Opin. Neurobiol., 9, 223-227.

Kato, A., Ozawa, F., Saitoh, Y., Fukazawa, Y., Sugiyama, H. \& Inokuchi, K. (1998) Novel members of the Vesl/Homer family of PDZ proteins that bind metabotropic glutamate receptors. J. Biol. Chem., 273, 23969-23975.

Kato, A., Ozawa, F., Saitoh, Y., Hirai, K. \& Inokuchi, K. (1997) vesl, a gene encoding VASP/Ena family related protein, is upregulated during seizure, long-term potentiation and synaptogenesis. FEBS Lett., 412, 183-189.

Kawabata, S., Kohara, A., Tsutsumi, R., Itahana, H., Hayashibe, S., Yamaguchi, T. \& Okada, M. (1998) Diversity of calcium signaling by metabotropic glutamate receptors. J. Biol. Chem., 273, 17381-17385.

Konu, O., Kane, J.K., Barrett, T., Vawter, M.P., Chang, R., Ma, J.Z., Donovan, D.M., Sharp, B., Becker, K.G. \& Li, M.D. (2001) Region-specific transcriptional response to chronic nicotine in rat brain. Brain Res., 909, 194-203.

Koob, G.F. (1999) The role of the striatopallidal and extended amygdala systems in drug addiction. Ann. NY Acad. Sci., 877, 445-460.

Levin, E.D. (1992) Nicotinic systems and cognitive function. Psychopharmacology (Berl.), 108, 417-431.

Levin, E.D. \& Simon, B.B. (1998) Nicotinic acetylcholine involvement in cognitive function in animals. Psychopharmacology (Berl.), 138, 217-230.

Li, M.D., Kane, J.K., Parker, S.L., McAllen, K., Matta, S.G. \& Sharp, B.M. (2000) Nicotine administration enhances NPY expression in the rat hypothalamus. Brain Res., 867, 157-164.

Li, M.D., Konu, O., Kane, J.K. \& Becker, K.G. (2002) Microarray technology and its application on nicotine research. Mol. Neurobiol., 25, 265-285.

Li, M.D., MacDonald, G.J. \& Ford, J.J. (1997) Breed differences in expression of inhibin/activin subunits in porcine anterior pituitary glands. Endocrinology, 138, 712-718.

Manahan-Vaughan, D., Ngomba, R.T., Storto, M., Kulla, A., Catania, M.V., Chiechio, S., Rampello, L., Passarelli, F., Capece, A., Reymann, K.G. \& Nicoletti, F. (2003) An increased expression of the mGlu5 receptor protein following LTP induction at the perforant path-dentate gyrus synapse in freely moving rats. Neuropharmacology, 44, 17-25.

Mansvelder, H.D. \& McGehee, D.S. (2000) Long-term potentiation of excitatory inputs to brain reward areas by nicotine. Neuron, 27, 349-357.

Maren, S. (1999) Long-term potentiation in the amygdala: a mechanism for emotional learning and memory. Trends Neurosci., 22, 561-567.

McGehee, D.S., Heath, M.J., Gelber, S., Devay, P. \& Role, L.W. (1995) Nicotine enhancement of fast excitatory synaptic transmission in CNS by presynaptic receptors. Science, 269, 1692-1696.

Minami, I., Kengaku, M., Smitt, P.S., Shigemoto, R. \& Hirano, T. (2003) Longterm potentiation of mGluR 1 activity by depolarization-induced Homerla in mouse cerebellar Purkinje neurons. Eur. J. Neurosci., 17, 1023-1032.

Naisbitt, S., Kim, E., Tu, J.C., Xiao, B., Sala, C., Valtschanoff, J., Weinberg, R.J., Worley, P.F. \& Sheng, M. (1999) Shank, a novel family of postsynaptic density proteins that binds to the NMDA receptor/PSD-95/GKAP complex and cortactin. Neuron, 23, 569-582.

Nakanishi, S. (1994) Metabotropic glutamate receptors: synaptic transmission, modulation and plasticity. Neuron, 13, 1031-1037.

Nestler, E.J. (2002) Common molecular and cellular substrates of addiction and memory. Neurobiol. Learn. Mem., 78, 637-647.

O’Connor, J.J., Rowan, M.J. \& Anwyl, R. (1994) Long-lasting enhancement of NMDA receptor-mediated synaptic transmission by metabotropic glutamate receptor activation. Nature, 367, 557-559.

Ottersen, O.P. \& Landsend, A.S. (1997) Organization of glutamate receptors at the synapse. Eur. J. Neurosci., 9, 2219-2224.

Parkinson, J.A., Crofts, H.S., McGuigan, M., Tomic, D.L., Everitt, B.J. \& Roberts, A.C. (2001) The role of the primate amygdala in conditioned reinforcement. J. Neurosci., 21, 7770-7780.

Paterson, N.E., Semenova, S., Gasparini, F. \& Markou, A. (2003) The mGluR5 antagonist MPEP decreased nicotine self-administration in rats and mice. Psychopharmacology (Berl.), 167, 257-264.

Paxinos, G. \& Watson, C. (1986) The Rat Brain in Stereotaxic Coordinates. Academic Press, Sydney, p. 237.

Phillips, A.G., Ahn, S. \& Howland, J.G. (2003) Amygdalar control of the mesocorticolimbic dopamine system: parallel pathways to motivated behavior. Neurosci. Biobehav. Rev., 27, 543-554. 
Pidoplichko, V.I., DeBiasi, M., Williams, J.T. \& Dani, J.A. (1997) Nicotine activates and desensitizes midbrain dopamine neurons. Nature, 390, 401-404.

Pidoplichko, V.I., Noguchi, J., Areola, O.O., Liang, Y., Peterson, J., Zhang, T. \& Dani, J.A. (2004) Nicotinic cholinergic synaptic mechanisms in the ventral tegmental area contribute to nicotine addiction. Learn. Mem., 11, 60-69.

Pisani, A., Calabresi, P., Centonze, D. \& Bernardi, G. (1997) Enhancement of NMDA responses by group I metabotropic glutamate receptor activation in striatal neurones. Br. J. Pharmacol., 120, 1007-1014.

Roche, K.W., Tu, J.C., Petralia, R.S., Xiao, B., Wenthold, R.J. \& Worley, P.F. (1999) Homer $1 \mathrm{~b}$ regulates the trafficking of group I metabotropic glutamate receptors. J. Biol. Chem., 274, 25953-25957.

Rodrigues, S.M., Bauer, E.P., Farb, C.R., Schafe, G.E. \& LeDoux, J.E. (2002) The group I metabotropic glutamate receptor mGluR5 is required for fear memory formation and long-term potentiation in the lateral amygdala. J. Neurosci., 22, 5219-5229.

Ryabinin, A.E., Wang, Y.M. \& Finn, D.A. (1999) Different levels of Fos immunoreactivity after repeated handling and injection stress in two inbred strains of mice. Pharmacol. Biochem. Behav., 63, 143-151.

Sabban, E.L. \& Gueorguiev, V.D. (2002) Effects of short- and long-term nicotine treatment on intracellular calcium and tyrosine hydroxylase gene expression. Ann. NY Acad. Sci., 971, 39-44.

Sala, C., Futai, K., Yamamoto, K., Worley, P.F., Hayashi, Y. \& Sheng, M. (2003) Inhibition of dendritic spine morphogenesis and synaptic transmission by activity-inducible protein Homerla. J. Neurosci., 23, 6327-6337.

Sala, C., Piech, V., Wilson, N.R., Passafaro, M., Liu, G. \& Sheng, M. (2001) Regulation of dendritic spine morphology and synaptic function by Shank and Homer. Neuron, 31, 115-130.

Schilstrom, B., Nomikos, G.G., Nisell, M., Hertel, P. \& Svensson, T.H. (1998) $\mathrm{N}$-methyl-D-aspartate receptor antagonism in the ventral tegmental area diminishes the systemic nicotine-induced dopamine release in the nucleus accumbens. Neuroscience, 82, 781-789.

Soloviev, M.M., Ciruela, F., Chan, W.Y. \& McIlhinney, R.A. (2000a) Molecular characterisation of two structurally distinct groups of human homers, generated by extensive alternative splicing. J. Mol. Biol., 295, 1185-1200.

Soloviev, M.M., Ciruela, F., Chan, W.Y. \& McIlhinney, R.A. (2000b) Mouse brain and muscle tissues constitutively express high levels of Homer proteins. Eur. J. Biochem., 267, 634-639.

Swanson, C.J., Baker, D.A., Carson, D., Worley, P.F. \& Kalivas, P.W. (2001) Repeated cocaine administration attenuates group I metabotropic glutamate receptor-mediated glutamate release and behavioral activation: a potential role for Homer. J. Neurosci., 21, 9043-9052.
Szumlinski, K.K., Dehoff, M.H., Kang, S.H., Frys, K.A., Lominac, K.D., Klugmann, M., Rohrer, J., Griffin, 3rd, W., Toda, S., Champtiaux, N.P., Berry, T., Tu, J.C., Shealy, S.E., During, M.J., Middaugh, L.D., Worley, P.F. \& Kalivas, P.W. (2004) Homer proteins regulate sensitivity to cocaine. Neuron, 43, 401-413.

Taber, M.T., Das, S. \& Fibiger, H.C. (1995) Cortical regulation of subcortical dopamine release: mediation via the ventral tegmental area. J. Neurochem., 65, 1407-1410.

Tu, J.C., Xiao, B., Naisbitt, S., Yuan, J.P., Petralia, R.S., Brakeman, P., Doan, A., Aakalu, V.K., Lanahan, A.A., Sheng, M. \& Worley, P.F. (1999) Coupling of mGluR/Homer and PSD-95 complexes by the Shank family of postsynaptic density proteins. Neuron, 23, 583-592.

Tu, J.C., Xiao, B., Yuan, J.P., Lanahan, A.A., Leoffert, K., Li, M., Linden, D.J. \& Worley, P.F. (1998) Homer binds a novel proline-rich motif and links group 1 metabotropic glutamate receptors with IP3 receptors. Neuron, 21, 717-726.

Turrigiano, G.G. \& Nelson, S.B. (2000) Hebb and homeostasis in neuronal plasticity. Curr. Opin. Neurobiol., 10, 358-364.

Walker, D.L. \& Davis, M. (2002) The role of amygdala glutamate receptors in fear learning, fear-potentiated startle, and extinction, Pharmacol. Biochem. Behav., 71, 379-392.

Winer, J., Jung, C.K., Shackel, I. \& Williams, P.M. (1999) Development and validation of real-time quantitative reverse transcriptase-polymerase chain reaction for monitoring gene expression in cardiac myocytes in vitro. Anal. Biochem., 270, 41-49.

Wonnacott, S. (1997) Presynaptic nicotinic ACh receptors. Trends Neurosci., 20, 92-98.

Xiao, B., Tu, J.C., Petralia, R.S., Yuan, J.P., Doan, A., Breder, C.D., Ruggiero, A., Lanahan, A.A., Wenthold, R.J. \& Worley, P.F. (1998) Homer regulates the association of group 1 metabotropic glutamate receptors with multivalent complexes of homer-related, synaptic proteins. Neuron, 21, 707-716.

Xiao, B., Tu, J.C. \& Worley, P.F. (2000) Homer: a link between neural activity and glutamate receptor function. Curr. Opin. Neurobiol., 10, 370-374.

Xie, X., Berger, T.W. \& Barrionuevo, G. (1992) Isolated NMDA receptormediated synaptic responses express both LTP and LTD. J. Neurophysiol., 67, 1009-1013.

Yu, S.P., Sensi, S.L., Canzoniero, L.M., Buisson, A. \& Choi, D.W. (1997) Membrane-delimited modulation of NMDA currents by metabotropic glutamate receptor subtypes $1 / 5$ in cultured mouse cortical neurons. J. Physiol. (Lond.), 499, 721-732.

Zheng, F. \& Gallagher, J.P. (1992) Metabotropic glutamate receptors are required for the induction of long-term potentiation. Neuron, 9, 163-172. 